\title{
Historicizing the Study of Sunni Islam in the Ottoman Empire, c. 1450-c. $175^{\circ}$
}

\author{
Tijana Krstić
}

Recent studies in anthropology have increasingly come to understand Islam as a "set of interpretative resources and practices" accumulated over centuries through engaging with the key sources of Islam - the Quran, hadith, and prophetic custom (sunna). In this view, being a Muslim is a result of individual and collective efforts "to grapple with those resources and shape those practices in meaningful ways," giving their practitioners a sense of being embedded in long chains of authenticated interpretation and transmission of a tradition. ${ }^{1}$ Tradition is here not understood as a simple replication of the past; it is not passively received but rather actively constructed in a particular social and historical setting, simultaneously affirming a "synchronic bond between actors" in a given community and extending it into the past, into a "diachronic community" of Muslims. ${ }^{2}$ The implication of this approach, which also informs the present volume, is that such efforts to engage with authenticating texts and acts as well as methods of interpretation of Islam transpired throughout history, resulting in numerous historically and contextually contingent understandings of what it means to be a Muslim. However, that is hardly reflected in mainstream historiography, which has long associated dynamism and evolution in Islamic traditions and their interpretation only with the so-called classical or formative period, from the first/seventh to the seventh/thirteenth century, while envisioning stagnation, decline, and derivativeness as the defining features of the centuries that followed. This has been particularly true for the geographies considered marginal to what is often viewed as the "core lands" of Islam (which for the late "formative" period typically means Syria, Egypt, and the Hijaz). ${ }^{3}$

1 Bowen, A new anthropology 3.

2 Grieve and Weiss, Illuminating the half-life of tradition 3. See also Anjum, Islam as a discursive tradition.

3 For a discussion of how this notion of "core lands" has been influencing writing about Islamic history, see Bashir, On Islamic time. 
Fortunately, recent publications suggest that this trend is beginning to change and that the "post-formative" Islamic discourses from North Africa to India and beyond are slowly coming into a sharper focus. ${ }^{4}$ In seeking to capture what might be special about studying post-formative Muslim communities, Shahab Ahmed suggested that they drew on the synthesis of discursive and institutional elements built up during the first six centuries of Islam, finding themselves "equipped and disposed to strike out in new constructions, trajectories, tenors, and expressions of what it means to be Muslim.." The present volume epitomizes this growing scholarly interest in historicizing Islamic discourses and practices of the post-formative era by exploring their embeddedness in the changing political and intellectual landscape of post-Mongol Eurasia, which was informed by the demise of the late medieval Timurid polities and the Mamluk sultanate, and the building of the Ottoman, Safavid, and Mughal empires. The essays focus on how Muslims within a particular polity that emerged at this time - the Ottoman Empire-engaged not only with the textual sources of Islam but also with what Ahmed terms the "Con-Text of Revelation," namely the body of meaning that previous generations of Muslims produced in their hermeneutical engagement with the Revelation as to what it means to be a Muslim in general and, within the framework of this study, a Sunni Muslim in particular. ${ }^{6}$

As scholars of Islam have noted, the terms sunna and "Sunni" themselves have a complicated history, although their evolution and connotations are rarely explored beyond the fifth/eleventh century. Today, sunna is understood to mean "generally approved standard or practice introduced by the Prophet as well as the pious Muslims of olden days." ${ }^{7}$ However, the term itself is of

4 See especially Bauer, Die Kultur and Ahmed, What is Islam? Important contributions to understanding the new intellectual trends of the period include Pourjavady, Philosophy; Moin, The millenial sovereign; Hagen, The order of knowledge; Burak, The second formation; ElRouayheb, Islamic intellectual history; Binbaş, Intellectual networks; Atçl, Scholars and sultans; Yllmaz, Caliphate redefined; Markiewicz, The crisis of kingship, to name just a few recent studies particularly relevant to the present collection.

5 Ahmed, What is Islam? 81.

6 Ahmed, What is Islam? 356-357. This body of meaning is not purely textual but includes a whole array of emotions, practices, actions, aesthetic choices, etc. that are meaningful to their actors in terms of Islam. Ahmed understands "Con-Text" as "the full encyclopaedia of epistemologies, interpretations, identities, persons and places, structures of authority, textualities and intertextualities, motifs, symbols, values, meaningful questions and meaningful answers, agreements and disagreements, emotions and affinities and affects, aesthetics, modes of saying, doing and being, and other truth-claims and components of existential exploration and meaning-making in terms of Islam that Muslims acting as Muslims have produced."

7 Juynboll, Sunna. 
pre-Islamic origin, and as Ignaz Goldziher observed, it seems to have originally referred to a general "standard of correctitude" that was subsequently restricted to the conduct of the Prophet and his Companions as exemplar and norm. ${ }^{8}$ Nevertheless, during the first two and a half centuries of Islam the term sunna retained a certain vagueness, especially when used in different constructions such as aṣhāb sunna, ahl al-sunna, or ahl al-sunna wa-l-jamā'a (People of the Sunna and the community), from which the term "Sunni" is derived..$^{9}$ As Marshall Hodgson noted, before the third/ninth century various groups and factions used the term "Sunni" to define their own understanding of belief and practice as exemplary and laudable and to dismiss opponents in the context of political and theological discussions: "Some used it for those devoted purely to the use of hadith reports (sunnah), without speculative discussion (kalâm). It was used later, among those who were willing to accept kalâm discussion at all, for the Ash'arî or Mâturîdî schools of kalâm as against the Mu'tazilî; it was used by Shari'ah-minded zealots to distinguish Shari'ah-minded people from the Ŝufî mystics; and generally as the equivalent of English 'orthodox.'”10 This early history of the term reminds us that rather than being perceived, as it is today, primarily in contrast to Shi'ism, belonging to the ahl al-sunna wa-ljama $\bar{a}^{\prime} a$ was juxtaposed to belonging to $a h l a l-b i d a$ - those who introduce innovative dogmatic ideas. ${ }^{11}$ The stance championed by the Party of 'Ali (Shi'ites) that it was 'Alī b. Abī Ṭālib rather than Abū Bakr who was the rightful heir of the Prophet, was part of the spectrum of beliefs and practices that were identified as blameworthy innovation, and that contributed to the process of calibration of what ahl al-sunna wa-l-jamāa $a$ stood for in the early centuries of Islam. ${ }^{12}$ The early phases of this process have been better studied, and scholars have pointed to the Mihna, the so-called Inquisition instigated by the caliph alMa'mūn (198-218/813-833), as the pivotal event in the formation of the ahl alsunna wa-l-jamā'a and "crystallization of Sunnism as we known it."13 Some have argued that "from the 4 th/1oth century onwards the term sunna did not acquire new connotations or nuances,"14 while others see a "full blown" or fully real-

8 Goldziher, Muslim studies ii, 25-26. In contrast, Juynboll notes that in the "Djāhiliyya" sunna denoted any type of conduct, good or bad.

$9 \quad$ The question was examined in detail by scholars interested in the evolution and mutual relationship between the concepts of sunna and hadith. See, for instance, Melchert, The piety; Nawas, The appellation șăhib sunna.

10 Hodgson, The venture of Islam i, 278.

11 On the ahl al-bida in contrast to ahl al-sunna, see Juynboll, Sunna.

12 On the evolution of the Sunni creed, see Wensinck, The Muslim creed.

13 Nawas, The appellation șăhib sunna 22.

14 Juynboll, Sunna. 
ized Sunnism emerge only in the fifth/eleventh century. ${ }^{15}$ The present volume builds on these studies, which emphasize that "Sunnism" itself has a history, and explores what that history was beyond the "classical period" and beyond the "core lands."

The mid-ninth/fifteenth century witnessed a profound reconfiguration of the Islamic world, propelling new geographical areas into a position of prominence and restructuring scholarly and trade networks, with Istanbul and various Anatolian and Balkan cities emerging as the new key nodes in the communication between and among the centers of Islamic learning, both to the southwest and to the east. ${ }^{16}$ Recent studies on these developments highlight the fact that the notion of the "core lands" is not a useful category in spatial terms; however, the claim that "the core" of Islam resided in particular geographies and scholarly genealogies associated with them certainly played an important discursive role in the encounter among the "Arab," "Rumi," and "Ajam" ulama during the era in question, especially as they embarked on the legitimation of different competing imperial agendas. ${ }^{17}$ The present collection looks into how various Ottoman Muslims, stemming largely from the lands of Rum (Anatolia and the Balkans), understood and engaged with the notions of the Sunni tradition, to which they were exposed through various chains of transmission, to define what it meant to be a Sunni Muslim and what constituted correct belief and practice. The essays also explore how these notions of "orthodoxy" and "orthopraxy" were informed by the Ottoman experiences of empire building between the late ninth/fifteenth and early twelfth/eighteenth centuries.

Students of Islam largely agree that the notion of "orthodoxy," emerging from the study of Christianity, is inadequate for analysis of the dynamics between "belief" and "unbelief" in Islam. They do so on the grounds that, unlike in Christianity, in Islam there is no clergy or ecumenical councils who would be authorized to define "correct" belief; Islamic law is fundamentally pluralistic and envisions different ways of doing things correctly, and there are multiple "hermeneutical paths," as Ahmed put it, for reaching the Truth. At the same time, however, most scholars recognize that, for want of a better term, the

15 Barkey, The formation of Islam; Reinhart, On Sunni sectarianism.

16 The most compelling visualization of the reconfigurations of the Islamic scholarly networks between 1100 and 1800 , including the visible shift in the late fifteenth century, can be found in Romanov, Algorithmic analysis (for the maps see S241-243). For the intellectual networks developing in this changing political landscape, see especially Binbaş, Intellectual networks and Markiewicz, The crisis of kingship.

17 For recent studies that explore this competitive engagement see Kuru, The literature of Rum; Pfeifer, Encounter after the conquest; Burak, The second formation 65-126; Meshal, Sharia $69-102$. 
notion of "orthodoxy" can be productively used if it is not viewed as a fixed body of opinions or a particular strand of Islam but rather as a discursive process whereby different social actors are vying to impose as authoritative their own understanding of which beliefs should be viewed as "correct" and which do not meet that criterion-a process contingent on the configurations of power in a given social and historical context. ${ }^{18}$ The present volume builds on this understanding of orthodoxy and the related notion of "orthopraxy" (conceptualized here as a discursive process seeking to limit what constitutes "correct" practice), exploring their manifestations in the Ottoman context as well as the social and institutional developments that informed them. At the same time, the essays do not shy away from suggesting that the more concerted efforts to limit the multiplicity of the possible paths to Truth and circumscribe, if not eliminate, the "culture of ambiguity" that characterized medieval Islam, began in the early modern era with the Ottomans making decisive institutional strides in this direction, rather than being an outcome of Islam's encounter with postEnlightenment Europe, as suggested by recent studies. ${ }^{19}$ The volume, thus, approaches the notion of "orthodoxy" from both a synchronic and diachronic perspective, as a dynamic arising from a particular historical context, but also as an evolving mindset increasingly (although not universally) domesticated in the post-formative Islamic discourse as a consequence of building territorial, bureaucratic empires in the post-Mongol era. While it focuses on the Ottoman experience, the goal of the volume is not to argue for an Ottoman Sonderweg but rather to create the basis for a conversation about the comparable and possibly connected and entangled developments — or lack thereof—in other early modern Islamic (and other) empires.

The attempts to better understand the nature of Islamic discourses in the Ottoman Empire intensified over the last three decades as the field of Ottoman Studies began to shift from an overwhelming focus on socioeconomic history to include more concerted inquiries into cultural and intellectual developments. Up to that point, historians of the Ottoman Empire left the study of various communal and individual expressions of belief and practices of Islam largely to scholars from divinity schools and Islamic Studies departments, overlooking the embeddedness of these phenomena in the larger Ottoman social and institutional history. However, by the late 199os questions began to emerge about how and why the Ottoman Empire evolved from what historiography had

18 Asad, The idea; Knysh, 'Orthodoxy' and 'heresy'; Calder, The limits; El Shamsy, The social construction; Ahmed, What is Islam? 273-274.

19 See Bauer, Die Kultur 192-223; also Ahmed, What is Islam? 
characterized as a "syncretic" eighth/fourteenth-century polity, where ambiguity between Sunnism and Shi'ism (and even Islam and Christianity) prevailed, into an Islamic state concerned with defining and enforcing a "Sunni orthodoxy" by the early tenth/sixteenth century. Scholars focusing on the role of Sufis and Sufism in Ottoman society in particular took the lead in historicizing the debates concerning the nature and boundaries of Ottoman Sunnism and how they changed from the ninth/fifteenth to the eleventh/seventeenth centuries. ${ }^{20}$ Another important research focus-related in many ways to the changing attitudes toward Sufism-was Ottoman scholars' redefinition of the notion of heresy (zandaqa) as a legal term and its employment in the heresy trials that became common in the first half of the tenth/sixteenth century and recurred throughout the next 200 plus years. ${ }^{21}$

Traditional scholarship maintained that the Ottomans' closer alignment with "Sunni orthodoxy" was the result of the Ottoman conquest of the Arab Muslim territories of Syria and Egypt from the Mamluks in 922-923/1516-1517. In this view, the Ottomans' move away from a "metadox" 22 to an "orthodox" mindset in the early tenth/sixteenth century was understood as the outcome of the "core lands" exerting their influence on the "periphery" and exporting what was imagined as a "mature" and "stable" Sunni Islam. ${ }^{23}$ While some recent

$20 \quad$ Pioneering studies include Karamustafa, God's unruly friends; Clayer, Mystiques; Ocak's many articles and his monograph Osmanlı toplumunda zındıklar, and Terzioğlu's Sufi and dissident in the Ottoman Empire. Important insights into the nature of early Ottoman Islam and the role of dervishes were also put forward in Kafadar's Between two worlds, which, in turn, inspired numerous further studies on dervishes' role in Ottoman society and politics. Among these see especially Le Gall, A culture of sufism and Curry, The transformation.

21 A pioneering work on this topic was Üstün, Heresy and legitimacy, followed by Ocak's Osmanlı toplumunda zındıklar. Much still remains to be elucidated not only about the actual number of heresy trials that transpired in the early modern era but also about the legal and theological thinking that informed them. See especially Özen, İslâm hukukuna göre; Erünsal, XV-XVI. asır Osmanlı zendaka; Erünsal, Molla Lütfi; Al-Tikriti, Kalām in the service; Menekşe, Osmanlı toplumunda zındıklık, etc. Nenad Filipović is also currently working on a major study on this subject, started as a collaboration with late Shahab Ahmed, tentatively entitled Neither heaven nor hell fire.

22 Cemal Kafadar defined metadoxy as "a state of being beyond doxies, a combination of being doxy-naive and not being doxy-minded, as well as the absence of a state that was interested in rigorously defining and strictly enforcing an orthodoxy." See his Between two worlds 76 .

23 Representative of this view is Andrew Hess's wording: "Absorption of enormous territories peopled by Orthodox Muslims then joined success in the Holy War to place Ottoman society, still fluid in structure, more than ever under the stabilizing influence of an unchallenged and revived Islamic culture. In this area the transfer of the 'Ulema from Cairo to 
studies suggest that scholars and scholarship from the Mamluk lands indeed played an important role in the development of Ottoman Sunnism-albeit in a different way than imagined by traditional historiography-this line of research awaits further exploration. ${ }^{24}$ Instead, in recent years scholars have focused more on the rise of the Safavid Empire as a catalyst for the processes that led to the Sunni-Shi'i polarization in the post-Mongol Turco-Iranian world and the fashioning of a Sunni orthodoxy in the Ottoman Empire. A number of studies suggested that it was this threat to Ottoman legitimacy and aspirations to the leadership of the Muslim community that prompted the leading jurists of the Ottoman Empire to begin to more clearly delineate the beliefs of the "People of the Sunna and the Community" in contrast to those of the Kızılbaş, Räfidì (Tr. Rāfìī) and/or Shi'i followers of the Safavid shah. ${ }^{25}$ At the same time, research in the field of Safavid history has indicated that Ottoman attempts to define and police the boundaries of Sunni belief were mirrored by the Safavid efforts to construct a Twelver Shi'i orthodoxy over the course of the tenth/sixteenth century, not incidentally by employing Shi'i jurists from the Ottoman territory of Jabal Amil in Mt. Lebanon who were well versed in both the four Sunni schools of law and the Shi'i legal tradition. ${ }^{26}$ Taken together, these strands of research point to the heretofore insufficiently explored ways in which Rumi Muslims' interaction and competitive encounters with their coreligionists to the southwest and east affected both the nature of Ottoman Sunnism and the nature of religious politics in neighboring Muslim polities.

More recently, these questions were taken up in the context of the debate on "confessionalization" and "Sunnitization." Some scholars-a number of them contributors to this volume-have embraced these concepts to describe what they perceive as a growing concern within the Muslim communities in the "lands of Rum" with defining and enforcing the boundaries of correct belief and

Istanbul after the conquest of Egypt symbolized the final religious and social shaping of an Ottoman state whose population was now solidly Muslim." See Hess, The Ottoman conquest 70 .

24 See Pfeifer, Encounter after the conquest; Al-Tikriti, Ibn-i Kemal's confessionalism; Kaplan, An anti-Ibn 'Arabi; as well as articles by Pfeifer, Al-Tikriti, and Terzioğlu in this volume.

25 See, for instance, Savaş, XVI. asırda; Al-Tikriti, Kalām in the service; Dressler, Inventing orthodoxy, etc. Earlier seminal studies by Eberhard, Osmanische Polemik and Üstün, Heresy and legitimacy, have also been "rediscovered" and integrated into the conversation. As these studies point out, there was considerable semantic overlap in the way the terms Kızllbaş, Rāfiż̀ and Shi'i were used by early modern Ottoman authors, depending on the genre of the sources and agendas of the authors. On this issue see Atçl, The Safavid threat and Baltacıoğlu-Brammer, One word, many implications.

Abisaab, Converting Persia; Stewart, Polemics and patronage. 
practice, as well as the social impact of this phenomenon, beginning sometime in the second half of the ninth/fifteenth century and continuing over the following centuries. ${ }^{27}$ In the late 1970 os, when it was first articulated by H. Schilling and W. Reinhard, the concept of "confessionalization" was meant to resolve the impasse in German historiography between, on the one hand, confessionally inflected church history that focused exclusively on dogma, and a social/economic/Marxist approach, which excised religion from the study of history of the German state and society, on the other. Schilling and Reinhard, building on Ernst W. Zeeden's concept of "confession-building," argued that the building of the Catholic, Lutheran, and later Calvinist confessions not only had important conceptual parallels but also a similar social impact that reverberated far beyond the church, making an indelible mark on anything from gender relations, to art, culture, and early modern state formation. They termed this phenomenon "confessionalization" and postulated that the building of confessional communities entailed social disciplining that could be harnessed for political purposes, particularly for the goal of building a territorial state. ${ }^{28}$

By engaging with the notion of confessionalization and the massive scholarship it generated in the context of European historiography over the last few decades, Ottomanists working in this vein drew attention to the fact that sectarian polarization within both early modern Christendom and Islamdom transpired at the same time and had similar social consequences, raising the question - which we explore in detail elsewhere — of whether this was a coincidence and whether these processes were informed by some shared underlying dynamic. ${ }^{29}$ More pertinent to this volume, however, by engaging with the

27 Krstić, Illuminated by the light of Islam; Krstić, Contested conversions; Terzioğlu, Sufis in the age of state-building; Terzioğlu, Where catechism meets 'ilm-i ḥăl; Ivanyi, Virtue, piety and the law; Burak, Faith, law and empire; etc.

28 Reinhard, Zwang zur Konfessionalisierung?; Reinhard, Reformation, Counter- Reformation; Schilling, Confessional Europe.

29 This question is at the heart of the ERC Consolidator project entitled "The Fashioning of a Sunni Orthodoxy and the Entangled Histories of Confession-Building in the Ottoman Empire, 15th-18th Centuries" (OTTOCONFEssion, Project ID: 648498) of which the present volume is one of the outcomes. Placing the question of the Ottoman turn to the notions of correct belief and practice and the initiatives for reform and renewal of Islam into a broader Eurasian framework, this line of investigation opens up the possibilities for exploring the entanglements and connections in the sphere of the politics of piety across the geographical and confessional boundaries of the early modern world. It is mindful of the fact that in the Ottoman Empire Muslims coexisted with numerous Christian and Jewish communities that were profoundly affected by the confessional debates in early modern Europe through missionary efforts and various forms of human mobility, and raises the question of whether and how various communal understandings of "ortho- 
notion of confessionalization they also highlighted its potential for generating new inquiries into the heretofore neglected relationship between Islamic discourses and Ottoman society and politics. Rather than uncritically importing or "applying" a much criticized ${ }^{30}$ European paradigm to the study of Islamic history, they proposed to use it as a heuristic device that would inspire new questions to both well-known Ottoman sources and those traditionally explored only by experts in Islamic law and theology, such as various creeds, theological treatises and polemics, compendia of law, prayer and sermon collections, heresiographies, etc.- a goal that is central to this volume. As a result, recent research began to shed new light on the distinctly Ottoman experience of a broader trend that entailed a growing concern with "orthodoxy" and "orthopraxy" across early modern Eurasia. ${ }^{31}$

In a seminal article Derin Terzioğlu termed this Ottoman turn toward orthodoxy and orthopraxy "Sunnitization," which she defined as "the adoption by the Ottoman religious and political authorities of a series of policies to modify the behavior (and to a lesser extent the beliefs) of all their Muslim subjects in line with the precepts of Sunni Islam, as they were understood at the time."32 Over the last few years, this line of scholarship generated a considerable debate among students of early modern Islam, who began to look more closely at the nature of the phenomena in question and critically assess the terminology used to describe them. ${ }^{33}$ Scholars also began to examine more closely how the developments in the Ottoman context related to the late medieval post-Mongol dynamics. It is important to briefly review their most pertinent findings before discussing how the present volume expands this debate.

For instance, recent studies emphasize the role of Sufism and law as the two most significant intellectual resources that informed the narratives of sovereignty following the Mongol destruction of the caliphate in $656 / 1258$, as well as the Sunni-Shi'i polarization that emerged in the Turco-Iranian world by

doxy" and strategies of enforcing it were intertwined. On the project-related research exploring cross-confessional entanglements in the Ottoman Empire, see the forthcoming volume Entangled confessionalizations? Dialogic perspectives on the politics of piety and community building in the Ottoman Empire, 15th-18th centuries, Krstić and Terzioğlu (eds.). For a summary of criticisms accumulated over decades against the original confessionalization paradigm as formulated by Schilling and Reinhard, see Lotz-Heumann, The concept of "confessionalization."

31 Green, Islam in the early modern world; Parker, Reformation in global perspective.

32 Terzioğlu, How to conceptualize.

33 In addition to the studies cited previously and the present volume, another new edited collection directly engages with the issues outlined so far: see Erginbaş (ed.), Ottoman Sunnism. 
the early 9oos/15oos. Scholars have recently pointed to the prevalence of the eschatological notions of the Mahdi (the guided one) and mujaddid (renewer) as well as mystical concepts such as qutb (the pole or axis mundi) and alinsān al-kāmil (the perfect human being) in the self-fashioning of the Ottoman, Safavid, and Mughal rulers in the early 9oos/150os, foregrounding the role of the Sufi discourse in the new, alternative conceptualizations of universal authority. ${ }^{34}$ As Hüseyin Yllmaz has demonstrated, Sufis imagined a cosmic government where the ultimate authority rested in the most perfect human being (a mystical axis mundi/qutb) who possesses the spiritual authority (walāya) but is at the same time the caliph on earth. They reimagined the caliphate within a mystical framework and disassociated it from its historicist justifications and juristic basis, enabling various Sufis as well as other individualsincluding Ottoman sultans - to potentially claim universal, caliphal authority. But Sufis were not the only ones claiming walayya. The same type of authority was associated with the Shi'i imams, who as descendants of the Prophet through his daughter Fāțima and 'Alī ibn Abī Țālib claimed to embody both spiritual and temporal rulership. This made 'Alid genealogy a coveted trait among political contenders and the veneration of the ahl al-bayt (the household of the Prophet) a widespread feature of piety across the late medieval Turco-Iranian world, in some cases blurring while in others accentuating the boundaries between Sunni and Shi'i Islam (both of which were different at this point in time from the modern phenomena we understand by these terms today). ${ }^{35}$

In the early tenth/sixteenth century, the Ottoman sultan Selīm (d. 926/1520) and his son Süleymān (d. 974/1566), who sought to "pour themselves into the mold"36 of a messianic ruler and claim authority in this landscape dominated by the notions of mystical sovereignty, found themselves at a distinct disadvantage vis-à-vis the Safavid Shah Ismāîl (d. 930/1524), who was not only the spiritual leader (shaykh) of the Safavid Sufi order but was also believed by his followers to be the reincarnation of Imam 'Alī. When in 907/1501, upon the conquest of Tabriz, Shah Ismāîl proclaimed the conversion of heretofore Sunni Iran to Twelver Shi'ism - a process that would take a century to unfold - the stage was set for the onset of confessional polarization. As Hüseyin Yilmaz and

34 Fleischer, Lawgiver as messiah; Moin, The millenial sovereign; Yllmaz, Caliphate redefined; Melvin-Koushki, Early modern Islamicate empire.

35 McChesney, Waqf in Central Asia 268-269; Ylldırım, Sunni orthodox vs. Shi'ite heterodox?; Peacock, Islam, literature. On 'Alid descent as a tool of confessional boundary-making, see Pfeiffer, Confessional ambiguity.

$36 \quad$ See Moin, The millenial sovereign 54. 
Matthew Melvin-Koushki have noted, it was the competition over walāya, or spiritual authority and sovereignty, that led to the exaggeration of the confessional difference in the Turco-Iranian context. ${ }^{37}$ In other words, "sectarian consciousness was not the cause of the Ottoman-Safavid conflict but its consequence," and it was only with considerable effort in the coming two centuriesincluding by Sufis themselves - that the population living in these two empires was educated about the differences between Sunnism and Shi'ism, both of which were also being redefined in the process. ${ }^{38}$ Interestingly, Yllmaz's and Elke Eberhardt's research suggests that the primary resource the Ottomans used to educate themselves about the differences between the teachings of the Sunnis and Kızılbaş/Räfizis/shi'Sites, at least in the first half of the tenth/sixteenth century, were the works of the Sunni scholars fleeing the Safavid lands rather than the works of scholars from the Mamluk lands. However, it is likely that further research would reveal new aspects to this issue, given that in the Mamluk context anti-Shi'i sentiment was already quite pronounced since the late seventh/thirteenth century—as illustrated by various campaigns against the Shi'i population in Mt. Lebanon as well as a number of heresy trialsalthough it never reached the level of a concerted anti-Shi'i policy.39

In these parallel and dialogic early modern processes of "Sunnitization" and "Shi'itization," which were met with acceptance, rejection, and reappropriation, 'Alid loyalty and the veneration of the ahl al-bayt became a contested terrain that is increasingly drawing scholars' attention and has been analyzed under the rubric of "confessional ambiguity." 40 This research suggests that an "age of confessional polarization" did not simply replace the "age of confessional ambiguity," but rather that the discourses of confessional polarization and resistance to it coexisted, much like in the Ilkhanid period, but in a changed institutional and political environment that gave this dialectic a different social expression. ${ }^{41}$ Furthermore, there are indications that the process of differentiation and building of confessional communities did not affect only

37 Yllmaz, Caliphate redefined 257; Melvin-Koushki, Early modern Islamicate empire 369.

38 Yllmaz, Caliphate redefined 257; on the process of defining the Kızllbaş as Räfiżis and/or Shi'a, $256-266$.

39 See, for instance, Winter, Shams al-Dīn Muhammad; Wiederhold, Blasphemy; Levanoni, Takfir in Egypt. On the domestication of Mamluk learning in the lands of Rum, see Yildız, From Cairo to Ayasuluk; Kaplan, An anti-Ibn 'Arabi; and Pfeifer's, Al-Tikriti's, and Terzioğlu's articles in this volume.

40 See, for instance, Erginbaş, Problematizing Ottoman Sunnism; Erginbaş, Reappraising Ottoman religiosity; his article in this volume, and Terzioğlu, Confessional ambiguity.

41 On the coexistence of these discourses in the Ilkhanid period, see Pfeiffer, Confessional ambiguity. 
Sunnis and Shi'ites but also the Kızlbaş/Alevi communities who straddled the two empires. As recent studies suggest, the Kızlbaş/Alevi communities in the Ottoman Empire experienced during the tenth/sixteenth century the formation of their own "path" ( $y o l$, in Turkish), which entailed changes in their social organization, the emergence of a spiritual hierarchy, as well as a set of rituals and beliefs. Given that most of these communities inhabited rural areas and shared a predominantly oral culture, the contours of this "path," and the extent to which its social, ritual, and doctrinal bases were systematized, is a matter of new and ongoing inquiries, which have also been informed by the debates on Sunnitization and confessionalization in the Ottoman context. ${ }^{42}$

In addition to Sufism, recent research has drawn attention to Islamic law as a crucial resource for the new concepts of sovereignty and religious politics in the post-Mongol period. Guy Burak has argued that under the influence of Chinggis Khan's image as a divine legislator, post-Timurid rulers sought a new relationship with Islamic law, whereby different dynasties adopted a particular school of Sunni law as their official state school, not as an act of patronage but with the ambition of regulating the school's structures, authorities, and doctrines. ${ }^{43} \mathrm{In}$ a separate monograph Burak elaborated on this development in the context of the Ottoman adoption of the Hanafi school of law as their state madhhab, and the institutional changes that this development both reflected and enabled. ${ }^{44}$ These changes, which have been the focus of several important recent studies, entailed: the emergence of an imperial learned hierarchy topped by the state-appointed jurisconsult; the formation of an imperial educational system; the emergence of an imperial jurisprudential canon; and the systematic reconstruction of the Hanafi genealogy. ${ }^{45}$ Although the integration of the ulama into the fabric of the state and the rulers' aspirations to determine how law is implemented is increasing observable already in Ayyubid- and Zangid-period Syria and Egypt, and only gets stronger in the Mamluk era, as epitomized in the appointment and function of the four chief judges, unlike judges, jurists were not generally appointed by the ruler and were traditionally independent of the

42 On this point, see Ylldırım, Literary foundations; and Karakaya Stump, The KizilbashAlevis, especially $256-319$.

43 Burak, The second formation.

44 Ibid.

45 Although Imber's study Ebu's-su'ud was published more than two decades ago, it found a more concerted response only in the recent surge of studies on the imperial legal culture in Süleymān's time. See, for instance, Buzov, The lawgiver; Atçl, Scholars and sultans; Burak, The second formation; Meshal, Sharia, etc. For an important study of the effects of the imperial legal reforms on a particular locality, see Peirce, Morality tales. 
state in their interpretation of the law. ${ }^{46}$ In the Ottoman Empire, however, the sultan could intervene into choices of particular opinions within the Hanafi legal tradition through appointment of the chief jurist (known in the Ottoman context as şeyhü'l-isläm), although the power relationship between the sultans and chief jurists could also be reversed ${ }^{47}$ For this reason, some scholars have argued that it was in fact the ulama who primarily profited from this arrangement. ${ }^{48}$ Be it as it may, we see for the first time the rise of an "institutionally identifiable group of jurists affiliated with the dynasty" whose rulings generally reflected the state-endorsed legal solutions, with fatwa serving as the key mechanism of regulation within the school and the medium through which novel legal solutions were introduced by Ottoman jurists. ${ }^{49}$

The promotion of a particular Sunni school of law into a state school of law amounted to circumscribing the plurality of Islamic law in an unprecedented way, while the existence of a state-affiliated, learned imperial hierarchy created conditions conducive for a group of social actors to impose their opinion of what constitutes correct belief and practice of Islam (i.e., the conditions for the definition of "orthodoxy" and "orthopraxy").50 Like in the case of the influence of Sufism on Ottoman Sunni consciousness, the role of law in Ottoman society is better researched for the tenth/sixteenth century, with many questions still remaining open. One of those is certainly the extent to which the Ottomans were successful in—or even intent upon-imposing a Hanafi hegemony throughout its domains, especially in Syria and Egypt, as well as the extent and conditions under which they were open to embracing the solutions from other legal schools when it was deemed expedient. ${ }^{51}$

Besides the research on Sufism and law, another field within the umbrella of Ottoman studies that has generated significant insights for understanding the process of Sunnitization and the rise of a confessional consciousness in the Ottoman Empire has been architectural history. Gülru Necipoğlu's magisterial study of Architect Sinān's opus and imperial ideology of the Süleymānic era that informed it is particularly central in this respect. It inspired some of the earliest inquiries into the role of Sunnism in Ottoman imperial self-fashioning

\footnotetext{
46 See, for instance, Lev, Symbiotic relations; Rapoport, Legal diversity.

47 See Tezcan, The second Ottoman Empire.

48 See, in particular, Buzov, The lawgiver.

49 Burak, The second formation.

50 El Shamsy, The social construction 112-115; Ahmed, What is Islam? 270.

51 On the issue of Hanafi hegemony versus legal pluralism in Ottoman Egypt, see Ibrahim, Al-Sharani's response; Atçl, Memlükler'den Osmanlılar'a; on the openness to the opinions of other schools, see especially recent studies on Ottoman jurists' articulation of the concept of heresy (zandaqa) listed in footnote 21.
} 
by connecting the form and aesthetics of the tenth/sixteenth-century imperial monuments to the contemporary social, institutional, and ideological developments, including the rivalry with the Safavids. For instance, Necipoğlu drew attention to the spree of building mosques and masjids throughout the empire that was initiated by Sultan Süleymān in order to highlight the centrality of the congregational prayers in general and Friday prayers in particular to the Ottoman Sunni imperial identity - in contrast to that of the Safavids. Necipoğlu raised the question of the society's support for and participation in this imperial vision of a Sunni community and highlighted the importance of particular spaces - such as mosques and neighborhoods - as sites where normative behavior was enforced and where architecture, imperial ideology, and Islamic law intersected in novel ways. ${ }^{52}$ Building on Necipoğlu's seminal work, Maximilian Hartmuth has drawn attention to the shift that begins sometime in the mid- to late fifteenth century, from Ottoman cities having a single Friday mosque built by the sultan to having multiple Friday mosques that could be built by the members of the imperial elite. In addition to inquiring into the changes this introduced to the organization of congregational prayers and patterns of patronage, he also highlighted the accompanying changes to the architecture of the mosques that privileged ritual space in a new way. ${ }^{53}$ The question of how the changes in imperial ideology and politics of religion during the ninth/fifteenth century were reflected in space-specifically, in the transformation of the Ottoman "T-type" structures into mosques-is also examined in this volume by Çiğdem Kafescioğlu. Zeynep Yürekli's study, which situates the choice of particular members of the Ottoman military elite-Rumeli frontier lords - to patronize the shrines of the Bektashi Sufi order in Anatolia in the broader context of Ottoman imperial and religious politics in the late ninth/fifteenth century, has also led to important insights into how imperial authorities, increasingly aware of the revolutionary potential of the Sufi discourse, sought to Sunnitize less conformist Sufi orders and holy spaces associated with them. ${ }^{54}$

Again, the questions of the Sunnitization of space and the spatial dimensions of Sunnitization - with distinctions between "public" and "private" areas-have begun to be considered to some extent only for the early to midtenth/sixteenth century, but less so (or not at all) for the later periods. Fur-

$5^{2} \quad$ Necipoğlu, The age of Sinan.

53 Hartmuth, A late fifteenth-century change.

54 Yürekli, Architecture and hagiography; for important insights into the Sunnitization of the Sufi orders and spaces associated with them, see Terzioğlu, Sufis in the age of statebuilding; also Antov, The Ottoman "wild west." 
thermore, the question of the extent to which these new intersections between imperial ideology, piety, and space that scholars have begun to explore, mostly in urban settings (which had mosques), affected vast populations living in the villages (which in the best-case scenario-but not necessarily—had a masjid that was often just a house designated for the purpose of communal prayer), remains open and poses one of the most complex methodological challenges for the researchers working in this field. ${ }^{55}$

The present volume seeks to move away from the early tenth/sixteenth century that has until now dominated the research into Sunni-Shi'i polarization in the early modern era and the nature of Ottoman Sunnism by focusing on the vicissitudes of generating an Ottoman Sunni Hanafi consciousness and resistances to it in a longer perspective, looking both backward into the medieval period and forward into the eleventh/seventeenth and twelfth/eighteenth centuries. ${ }^{56}$ This approach allows authors to connect the insights from the research on tenth/sixteenth-century developments with a cluster of existing studies focusing on the emergence, starting in the early decades of the eleventh/seventeenth century, of various "sunna-minded" ${ }^{57}$ preachers, including the so-called Kadızadelis, who were fiercely critical of their fellow Sunni Muslims' practices and beliefs. ${ }^{58}$ This phenomenon has heretofore been considered in isolation, as

55 This question was recently taken up by James Grehan in his Twilight of the saints, where he points out that a vast majority of the premodern population in the Ottoman Arab provinces lived in the villages and had no access to religious infrastructure, whether mosques or churches. Grehan argues that in the absence of such access, countryside populations (including the outskirts of the cities) largely adhered to an "agrarian religion," which did not systematically embrace any set of dogma or laws, had a strong local coloring, was practical and eclectic, and often hostile to any notion of orthodoxy. See Twilight of the saints 19 .

$5^{6}$ This volume grew out of a workshop entitled "Rethinking Ottoman Sunnitization, ca. 1450-1700" that convened at the Central European University in Budapest, 25-27 August 2017, within the framework of the оттосONFESsion project. The editors would like to acknowledge the valuable contributions to the present discussion made by the participants of the conference who, for various reasons, did not end up contributing to this volume, especially Baki Tezcan, Sara Nur Yıldız, Devin Stewart, Aslıhan Gürbüzel, Yavuz Aykan, Ferenc Csirkés, Ahmet Kaylı, Rossitsa Gradeva, and Ayfer Karakaya-Stump.

57 Derin Terzioğlu suggested the term "sunna-minded" in order to emphasize that a variety of social actors from across the religious and political spectrum - not just preachers identified as the followers of Kaḍizāde Meḥmed (d. 1045/1635)—used the idiom of commitment to sunna and sharia in order to articulate criticism of and disappointment with the Ottoman social, political, and spiritual order in the seventeenth century. See her Sunnaminded Sufi preachers.

$5^{8}$ The seminal study on the subject that set the tone for subsequent research is Zilfi, The Kadizadelis. See also Çavuşoğlu, The Kadīzādeli movement; and Baer, Honored by the glory 
a departure from otherwise "tolerant" Ottoman ways, rather than as a manifestation of the ongoing reconsiderations of what it meant to be a Sunni Muslim in the Ottoman Empire, and a byproduct of the social and institutional changes that maintaining an empire, whose legitimacy was tied to the protection of the Sunni tradition, entailed. At the same time, many of the authors endeavor to trace how particular medieval Islamic genres, both textual and nontextualranging from prayer manuals, heresiographies, creeds, fatwa collections, biographical dictionaries, figh and kaläm treatises, and historiography to tekkes, imärets, and mosques-developed and were reinterpreted in the Ottoman period, thus consistently putting Ottomans' understandings of the Sunni tradition into a larger historical framework. In order to do this, the authors engage with the latest research on legal, theological, political, and architectural trends in the late medieval and early modern Islamic world.

The essays also represent a "second wave" of scholarship informed by the notions of "confessionalization" and "Sunnitization," building on and learning from the criticisms aimed at the original paradigm in the European context as well as the shortcomings of the earlier research on the turn toward Sunni orthodoxy in the Ottoman context. In this respect, the volume particularly seeks to move away from the statist bias that informs much of the earlier scholarship on both confessionalization in Europe and Islam in the Ottoman Empire. Rather than reifying the "state" and overemphasizing its role in the process of defining and imposing an "orthodoxy," the essays examine various agents of "Sunnitization" and emphasize the interplay among personal, local, communal, and imperial agendas.

In the first and most extensive part of the volume, the essays explore how various Ottoman authors across the social and political spectrum engaged with the classical and postclassical Sunni works on hadith, figh, and kaläm and processed their meaning in dialogue with the individual agendas and broader Ottoman realities. Thus, Helen Pfeifer examines how ninth/fifteenthand tenth/sixteenth-century Ottoman Rumi scholars viewed and accessed the study of hadith, arguing that their encounter with Arab scholars in the aftermath of the conquest of Syria and Egypt in 922-923/1516-1517 brought significant changes in madrasa curricula, making hadith studies more central not only to scholarly training but to the overall project of building a Sunni consciousness among the general population. Focusing on the study of kaläm, Nabil Al-Tikriti sets out to assess the nature of the Ottoman prince Korkud's

of Islam. On the reexamination of the relationship of the Kadızadelis to various social groups, see Terzioğlu, Sufi and dissident; Sariyannis, The Kadizadeli movement; Tuşalp Atiyas, The "Sunna-minded" trend. 
(d. 919/1513) contribution to the development of Ottoman Sunnism, examining his views on a variety of issues, from madrasa education to specific legal and theological positions. Delving deeply into the sources of several of Korkud's works and his interpretation of them, Al-Tikriti demonstrates how the rapprochement between Ash'ari and Maturidi theology, as well as the Hanafi and Shafi' $\mathrm{f}$ igh that characterized the late medieval intellectual landscape of Mamluk Syria, found echoes in Korḳud's oeuvre, marking him as a transitional author who prefigures certain trajectories in Ottoman Sunnism but takes a completely different course on others. In her contribution, Derin Terzioğlu examines how Ottoman authors from the tenth/sixteenth and eleventh/seventeenth centuries engaged with a specific figh work, al-Siyāsa al-shar'iyya, by a controversial late medieval intellectual, Ibn Taymiyya (d. 728/1328), exploring how a Hanbali treatise on the nature of a ruler's law was adopted and adapted by Ottoman Hanafi authors and to what ends. Terzioğlu also tackles the much debated issue of Ibn Taymiyya's influence on the Kadizadelis and the supposed existence of an Ottoman Hanafi Taymiyyan "school."

Tijana Krstić and Guy Burak focus on the question of how a Sunni identity was supposed to be interiorized as part of a comprehensive moral reform that the project, which was embraced by a variety of social actors, entailed. Krstić examines the changing sensibilities of the Hanafi and Maturidi scholars on the question of what constituted sufficient knowledge for one to be considered a true believer (mu'min) by tracing views expressed in the medieval Hanafi, Maturidi, and Ash'ari creedal texts and comparing them to the Ottoman catechisms ( $i l m-i$ h $\bar{a} l s$ ) in Turkish for common believers from the period between the ninth/fifteenth and eleventh/seventeenth centuries. She argues that there was a shift to a greater emphasis on detailed knowledge of faith and its interiorization in the early modern Ottoman Hanafi Maturidi tradition, echoing wider theological trends of the age of confessional polarization. Burak's essay looks at the Ottoman commentaries on prayers, invocations, and supplications, including on Muhammad ibn Sulaymān al-Jazūlī's (d. 869/1465) Dalä̀il al-khayrät wa-shawāriq al-anwār, from the tenth/sixteenth to the twelfth/eighteenth centuries to examine how the relationship between belief and understanding on the one hand and performative deeds and speech acts on the other was perceived. He observes a shift over time from emphasis on simply reciting an appropriate prayer in a given situation, even if one does not understand its meaning, to understanding the essence of specific prayers and seeking to comprehend their deeper meaning - a development that accounts for the proliferation of prayer commentaries in the late eleventh/seventeenth and early twelfth/eighteenth century. Seeking to bridge the communal and individual aspects of building a Sunni Hanafi consciousness, Nir Shafir examines both 
how individual Ottoman authors engaged with the medieval heresiographical tradition in producing their own texts in the tenth/sixteenth and eleventh/seventeenth century, and how the Ottoman audience of these texts engaged with the notion of confessional difference based on the marginal notes in surviving Ottoman manuscripts. His article eloquently demonstrates how heresiographical discourse and labels were consistently repurposed throughout medieval and early modern Islamic history to fit the debates of the day and the changing ideas and expressions of what it meant to be a Sunni.

Moving on from particular authors and their takes on the questions of tradition and orthodoxy, the second part of the volume looks more closely at the intersection of imperial, communal, and spatial dimensions of the "sunnaminded" turn. Grigor Boykov outlines the process by which the tekkes of the Abdals of Rum in Eastern Thrace were progressively converted to the more sunna-minded Halveti convents by the mid-tenth/sixteenth century through the partnership between particular Halveti Sufi shaykhs and their patron Sokollu Mehmed Pasha (grand vizier, 973-986/1565-1579). Çiğdem Kafescioğlu highlights the centrality of cooperation between the sultan and his kul elite in the second half of the ninth/fifteenth century in rearticulating the architectural language of the spaces that initially served both for various types of congregation and prayer ('imāret) into spaces reserved exclusively for congregational prayer (mosque), which was in line with the new, imperial understanding of Sunni orthopraxy and community. Ünver Rüstem takes the story of the parallel evolution in Sunni imperial ideology and architecture all the way into the late twelfth/eighteenth century, focusing on imperial mosques as sites at which the sultan's authority and leadership of the Sunni community was negotiated and constantly redefined through interaction among the members of the dynasty, Sufis, ulama, and the wider population of the Ottoman capital. The synergy as well as tension between a neighborhood imam and his congregation in the process of social disciplining and articulation of Sunni norms in the Ottoman context is brought into sharp relief in Evren Sünnetçioğlu's essay, which examines how the issue of the five daily congregational prayers and who could lead them became central both to imperial ideology and to communal relations. In addition to putting emphasis on the cooperative and negotiated nature of Sunnitization, these papers also stress the importance of space and understanding the changing social relations and pious sensibilities in and through particular spatial contexts, be it a mosque, a tekke, a neighborhood, or a region such as Eastern Thrace.

Much of the early wave of scholarship on the fashioning of Sunni orthodoxy in the Ottoman Empire emphasized the punitive character of the phenomenon by focusing on the Ottoman persecution of various nonconformist 
Sufis, heretics (zindīq) and other deviants (mulhid), Kızılbaş, and Räfì̀is, typically by focusing on the fatāwa and legal treatises of the leading Ottoman jurists or the records of the important imperial affairs. ${ }^{59}$ In contrast, the essays in the third part of the volume explore not only discursive moves toward achieving some sort of confessional purity and clarity, but also ways in which various social groups and individuals resisted the notion of an "orthodoxy" or sought to maintain space for confessional difference, ambiguity, or even unity under the umbrella of both the Ottoman state and Islam. Thus, Ayşe Baltacioğlu-Brammer takes a closer look at the differentiation within the Kızılbaş community - which is too often imagined as homogenous and marginalized - to recognize the variety of ways in which Kızllbaş groups and individuals could negotiate their place, status, and privileges within the imperial system, often based on the economic and military importance they held in a particular locale, especially in borderland areas. A different take on the space for confessional ambiguity and difference within Ottoman Sunni ideology is taken by Vefa Erginbass, who examines the place of the veneration of the House of the Prophet (what he terms "ahl al-baytism") in early modern Ottoman Sunnism. He explores Ottoman historians' views on Yazīd ibn Mu'āwiya, the second caliph of the Umayyad dynasty, whose role in the killing of the Prophet's grandson Husayn at the battle of Karbala made him the object of cursing by Shi'ites. Erginbass shows that major Ottoman historians of the tenth/sixteenth and eleventh/seventeenth centuries shared this resentment for Yazìd and cultivated great respect for the ahl al-bayt, examining the extent to which their views were affected by Ottoman-Safavid competition and Kadızadeli preaching. Selim Güngörürler, on the other hand, highlights the discourse of "deconfessionalization," so to say, in the context of a particular genre- the diplomatic correspondence between the Ottomans and Safavids between 1048/1639 and the $1130 \mathrm{os} / 1720{ }^{60}{ }^{60}$ His essay is an interesting counterpart to the work on the emergence of sectarian consciousness in the tenth/sixteenth century, since it demonstrates that once the Ottoman claims to greater caliphal authority were accepted by the Safavids and the period of peace between the empires set in after the Treaty of Zuhab in 1048/1639, sectarian consciousness could be downplayed or even replaced by the discourse of brotherhood and unity under the banner of Islam - at least on the platform of diplomatic relations. Altogether, these essays drive home a crucial point, which is that different understandings

59 See, for instance Imber, The persecution; Üstün, Heresy and legitimacy; Ocak, Osmanlı toplumunda zindıklar, etc. For an important critique of this approach see Winter, The Shitites of Lebanon.

6o For a related argument see Özervarl, Between tension and rapprochement. 
of Sunnism and perspectives on what it was to be a Sunni Muslim emerge from different Ottoman administrative and narrative genres, even when they were produced in the exact same period or by the people closely affiliated with the state.

Given that the essays reflect a relatively new field of inquiry that is still testing a variety of approaches and analytical terms that might best characterize processes at hand, there is no attempt to homogenize the analytical language throughout the volume. Thus, some authors have chosen to engage with the concept of "confessionalization" and use the notion of "confession" to index sectarian divisions within Islam; others have opted to discuss their findings under the rubric of "Sunnitization" and examine and historicize various labels associated with belonging to the Sunni community, such as "Hanafi" and "Shafi'i," or "Maturidi" and "Ash'ari," subjecting them to contextual and relational analysis. Importantly, a number of essays explore the meaning of the term madhhab (Tr. mezheb) in various discursive and genric contexts, drawing attention to the fact that this term had a much broader usage in Ottoman texts of the period than is usually recognized in the secondary literature: rather than only indicating a scholar belonging to a particular legal school (Hanafi, Shaf'i, Maliki, or Hanbali), it is also used by Ottoman authors to indicate adherence to a particular school of kalām (Maturidi, Ash'ari, etc.) as well as a particular sect (or denomination) of Islam (Sunni, Shi'i, Kızılbaş, etc.).

As an edited volume that aims to map new directions in the research on early modern Ottoman Sunnism, the present collection does not aspire to comprehensiveness and inevitably leaves unaddressed various questions, sources, and methodological approaches, and addresses some parts of the period under discussion in greater detail than others. Perhaps most notably, it is heavily skewed toward intellectual and cultural history, while fewer articles focus on the social or economic aspects of the problem and examine how particular communities' socioeconomic niche and geographical provenance, or individuals' class and gender, informed their experiences and reactions to the questions of Sunni orthodoxy and orthopraxy. It is by no means the editors' intention to suggest that those perspectives or the sources they could be gleaned from, such as population registers, court records, various individual petitions to the sultan, or registers of important imperial affairs, are in any way less important. Rather, it is a reflection of the endeavor to introduce new, heretofore largely untapped, sources into the discussion and point to a considerable polyphony in the Ottoman discourses on Sunnism by consulting a variety of genres that could help us generate new questions to be posed to better-studied sources, allowing us to understand their value in a new light and engage in multisource research. For instance, understanding the changing attitudes toward religious instruc- 
tion of the commoners articulated in the ilm-i hạls and the empire-wide initiatives to build mosques and masjids reflected in the imperial fermans together allow us to ask more informed questions about the fluctuation in the number of imams and hațībs indicated in the tenth/sixteenth- and eleventh/seventeenthcentury population registers for different regions (including villages) of the empire or prompt us to examine whether in the Ottoman tabaqāt literature preaching and preachers seem to be endowed with a different sort of social capital compared to the medieval examples of the same genre.

Ultimately, the goal of the volume is to open up new vistas onto how beliefs and ritual practices - as well as discourses about them-were integrated into the daily individual, family, and communal life as well as the life of the Ottoman Empire as a whole, allowing us to develop methodological tools for studying these issues on micro-, meso-, and macrolevels. Rather than postulating that the phenomenon of Sunnitization and various initiatives for imposing confessional (or hermeneutical) normativity were the defining feature of early modern Ottoman religious and social history, the volume historicizes the reasons why such initiatives arose in the first place and inquires after the actors who supported them and their discursive strategies, while also pointing to various ways in which these initiatives were subverted, tweaked, appropriated for personal ends, rejected, or completely ignored by Muslim groups and individuals. Some would perhaps be inclined to view this Ottoman dialectic between attempts to define and impose an orthodoxy and to resist and reject it as just another episode in a timeless dynamic present throughout Islamic history. Nevertheless, as this volume suggests, by exploring how various Ottoman authors interpreted the Sunni tradition by engaging with the views of previous generations of Muslims, early modern Ottoman context presents us with important new institutional, legal, theological, polemical, architectural, and other developments in conceptualizing what it meant to be a Muslim in general and a Sunni Muslim in particular. The essays, thus, highlight the importance of examining in detail various post-formative Islamic discourses in order to arrive at a more nuanced understanding of both Islamic and global early modern history.

\section{Bibliography}

Abisaab, R., Converting Persia: Religion and power in the Safavid empire, London, New York 2004.

Ahmed, S., What is Islam?: The importance of being Islamic, Princeton, NJ 2016.

Anjum, O., Islam as a discursive tradition: Talal Asad and his interlocutors, in Comparative studies of South Asia, Africa and the Middle East 27 (2007), 656-672. 
Antov, N., The Ottoman "wild west": The Balkan frontier in the fifteenth and sixteenth centuries, New York 2017.

Asad, T., The idea of an anthropology of Islam, Washington, DC 1986.

Atçıl, A., Memlükler'den Osmanlılar'a geçişte Mısır'da adlî teşkilât ve hukuk (922931/1517-1525), in Íslâm araştırmaları dergisi 38 (2017), 89-121.

Atçll, A., Scholars and sultans in the early modern Ottoman empire, New York 2017.

Atçl, A., The Safavid threat and juristic authority in the Ottoman Empire during the 16th century, in IJMES 49 (2017), 295-314.

Bashir, S., On Islamic time: Rethinking chronology in the historiography of Muslim societies, in History and theory 53 (2014), 519-544.

Baer, M.D., Honored by the glory of Islam: Conversion and conquest in Ottoman Europe, New York 2008.

Baltacıoğlu-Brammer A., One word, many implications: The term "Kızılbaş" in the early modern Ottoman context, in V. Erginbaş (ed.), Ottoman Sunnism: New perspectives, Edinburgh, 2019, 47-70.

Bauer, T., Die Kultur der Ambiguität: Eine andere Geschichte des Islams, Berlin 2011.

Binbaş, İ.E., Intellectual networks in Timurid Iran: Sharaf al-Dìn 'Alì Yazdī and the Islamicate republic of letters, New York 2016.

Bowen, J.R., A new anthropology of Islam, New York 2012.

Burak, G., Faith, law and empire in the Ottoman "age of confessionalization" (fifteenthseventeenth centuries): the case of "renewal of faith," in Mediterranean historical review 28 (2013), 1-23.

Burak, G., The second formation of Islamic law: The Hanafi school in the early modern Ottoman Empire, New York 2015.

Burak, G., The second formation of Islamic law: The post-Mongol context of the Ottoman adoption of a school of law, in Comparative studies in society and history 55 (2013), 579-6o2.

Buzov, S., The lawgiver and his lawmakers: The role of legal discourse in the change of Ottoman imperial culture, PhD diss., University of Chicago 2005.

Calder, N., The limits of Islamic orthodoxy, in F. Daftary (ed.), Intellectual traditions in Islam, London 2000, 66-86.

Clayer, N., Mystiques, état et société: les Halvetis dans l'aire balkanique de la fin du XV siècle à nos jours, Leiden 1994.

Curry, J., The transformation of Muslim mystical thought in the Ottoman Empire: The rise of the Halveti order, 1350-1650, Edinburgh 2010.

Çavuşoğlu, S., The Kadīzādeli movement: An attempt of Şeriat-minded reform in the Ottoman Empire, PhD diss., Princeton University 1990.

Dressler, M., Inventing orthodoxy: Competing claims for authority and legitimacy in the Ottoman-Safavid conflict, in H. Karateke and M. Reinkowski (eds.), Legitimizing the order: The Ottoman rhetoric of state power, Leiden 2005, 151-176. 
Eberhard, E., Osmanische Polemik gegen die Safawiden im 16. Jahrhundert nach arabischen Handschriften, Freiburg im Breisgau 1970.

El-Rouayheb, K., Islamic intellectual history in the seventeenth century: Scholarly currents in the Ottoman Empire and the Maghreb, New York 2015.

El Shamsy, A., The social construction of orthodoxy, in T. Winter (ed.), The Cambridge companion to classical Islamic theology, New York 2008, 97-117.

Erginbaş, V. (ed.), Ottoman Sunnism: New perspectives, Edinburgh 2019.

Erginbaş, V., Reappraising Ottoman religiosity in the last decades of the sixteenth century: Mustafa Darir's Siret and its Alid content, in V. Erginbaş (ed.), Ottoman Sunnism: New perspectives, Edinburgh 2019, 71-89.

Erginbaş, V., Problematizing Ottoman Sunnism: Appropriation of Islamic history and ahl al-baytism in Ottoman literary and historical writing in the sixteenth century, in JESHO 6o (2017), 614-646.

Erünsal, İ., XV-XVI. asır Osmanlı zendeka ve ilhad tarihine bir katkı, in JOs 24 (2004), 127-157.

Erünsal, İ., Molla Lütfi zındıklık ithamıyla mı öldürüldü? in Marmara üniversitesi hukuk fakültesi hukuk araştırmaları dergisi 21 (2015), 37-54.

Fleischer, C.H., Lawgiver as Messiah: The making of the imperial image in the reign of Suleyman, in G. Veinstein (ed.), Soliman le Magnifique et son temps, Paris 1992, 159177 .

Goldziher, I., Muslim studies, ii, ed. S.M. Stern, trans. C.R. Barber and S.M. Stern, Chicago, New York 1971.

Green, N., Islam in the early modern world, in J. Bentley, S. Subrahmanyam and M. Wiesner-Hanks (eds.), The Cambridge world history, Cambridge 2015, 358-386.

Grieve G.P. and R. Weiss, Illuminating the half-life of tradition: Legitimation, agency, and counter-hegemonies, in S. Engler and G.P. Grieve (eds.), Historicizing "tradition" in the study of religion, Berlin, New York 2005, 1-18.

Grehan, J., Twilight of the saints: Everyday religion in Ottoman Syria and Palestine, Oxford 2014.

Hagen, G., The order of knowledge, the knowledge of order: Intellectual life, in S. Faroqhi and K. Fleet (eds.), The Cambridge history of Turkey, ii, Cambridge 2013, 407-456.

Hartmuth, M., A late fifteenth-century change in the rapport of Friday mosque and Ottoman city? A case study of Macedonia, in A. Mollenhauer and M. Müller-Wiener (eds.), Beiträge zur islamischen Kunst und Archäologie vi (forthcoming).

Hess, A., The Ottoman conquest of Egypt (1517) and the beginning of the sixteenthcentury world war, in IJMES 4 (1973), 55-76.

Hodgson, M.G.S., The venture of Islam, i, Chicago, London 1974.

Ibrahim, A.F., Al-Sharānī”s response to legal pluralism: A theory of legal pluralism, in Islamic Law and Society 20 (2013), 110-140.

Imber, C.I., Ebu's-su'ud: The Islamic legal tradition, Palo Alto 1997. 
Imber, C.I., The persecution of the Ottoman Shi'ites according to the muhimme defterleri, $15^{6} 5^{-1585}$, in Der Islam $5^{6}$ (1979), 245-273.

Ivanyi, K., Virtue, piety and the law: A study of Birgivi Mehmed Efendi's al-Tariqa alMuhammadiyya, PhD diss., Princeton University 2012.

Juynboll, G.H.A. and D.W. Brown, Sunna, in $E I^{2}$.

Kafadar, C., Between two worlds: The construction of the Ottoman state, Berkeley, Los Angeles 1995 .

Kafescioğlu, Ç., Constantinopolis-Istanbul: Cultural encounter, imperial vision, and the construction of the Ottoman capital, University Park, PA 2009.

Kaplan, C., An anti-Ibn 'Arabi (d. 1240) polemicist in sixteenth-century Ottoman Istanbul: Ibrahim al-Halabi (d. 1549) and his interlocutors, MA thesis, CEU 2019.

Karakaya-Stump, A., The Kizilbash-Alevis in Ottoman Anatolia: Sufism, politics, and community, Edinburgh 2020.

Karamustafa, A., God's unruly friends: Dervish groups in the Islamic later middle period, 1200-1550, Salt Lake City 1994.

Knysh, A., "Orthodoxy" and "heresy" in medieval Islam: An essay in reassessment, in $M W 83$ (1993), 48-67.

Kuru, S., The literature of Rum: The making of a literary tradition (1450-160o), in S. Faroqhi and K. Fleet (eds.), Cambridge history of Turkey, ii, Cambridge 2013, 548-592.

Krstić, T., Illuminated by the light of Islam and the glory of the Ottoman sultanate: Narratives of conversion to Islam in the age of confessionalization, in Comparative studies in society and history 51 (2009), 35-63.

Krstić, T., Contested conversions to Islam: Narratives of religious change and communal politics in the early modern Ottoman Empire, Palo Alto 2011.

Le Gall, D., A culture of Sufism: Naqshbandis in the Ottoman world, 1450-1700, Albany 2005 .

Lev, Y., Symbiotic relations: Ulama and the Mamluk sultans, in MSR 13 (2009), 1-26.

Levanoni, A., Takfir in Egypt and Syria during the Mamlūk period, in C. Adang, H. Ansari, M. Fierro and S. Shmidtke (eds.), Accusations of unbelief in Islam: A diachronic perspective on Takfir, Leiden, Boston, New York 2016, 155-188.

Lotz-Heumann, U., The concept of "confessionalization": A historiographical paradigm in dispute, in Memoria y civilización 4 (2001), 93-114.

Markiewicz, C.A., The crisis of kingship in late medieval Islam: Persian emigres and the making of Ottoman sovereignty, Cambridge 2019.

McChesney, R.D., Waqf in Central Asia: Four hundred years in the history of a Muslim shrine, 1480-1889, Princeton 1991.

Melchert, C., The piety of the hadith folk, in IJMES 34 (2002), 425-439.

Melvin-Koushki, M., Early modern Islamicate empire: New forms of religiopolitical legitimacy, in A. Salvatore, R. Tottoli and B. Rahimi (eds.), The Wiley-Blackwell history of Islam, Malden, MA 2018, 353-375. 
Menekşe, Ö., Osmanlı toplumunda zındıklık: Patburnuzade örneğinde bir inceleme, Istanbul 2019.

Meshal, R.A., Sharia and the making of the modern Egyptian: Islamic law and custom in the courts of Ottoman Cairo, Cairo, New York 2014.

Moin, A., The millenial sovereign: Sacred kingship and sainthood in Islam, New York 2012.

Nawas, J.A., The appellation șạhib sunna in classical Islam: How Sunnism came to be, in Islamic law and society 23 (2016), 1-22.

Necipoğlu, G. The age of Sinan: Architectural culture in the Ottoman Empire, Princeton 2005.

Ocak, A.Y., Osmanlı toplumunda zındıklar ve mülhidler (15.-17. yüzyıllar), Istanbul 1998.

Özen, Ş., İslâm hukukuna göre zındıklık suçu ve Molla Lutfî̀nın idamının fıkhîliği, in İslâm araştırmaları dergisi 6 (2001), 17-62.

Özervarl, M.S., Between tension and rapprochement: Sunni-Shi'ite relations in the pre-modern Ottoman period, with a focus on the eighteenth century, in Historical research 90 (2017), 526-542.

Parker, C., Reformation in global perspective, in History compass 12 (2014), 924-934.

Peacock, A.C., Islam, literature and society in medieval Anatolia, Cambridge 2019.

Peirce, L.P., Morality tales: Law and gender in the Ottoman court of Aintab, Berkeley, Los Angeles 2003.

Pfeifer, H., Encounter after the conquest: Scholarly gatherings in 16th-century Ottoman Damascus, in IJMES 47 (2015), 219-239.

Pfeiffer, J., Confessional ambiguity vs. confessional polarization and the negotiation of religious boundaries in the Ilkhanate, in J. Pfeiffer (ed.), Politics, patronage and the transmission of knowledge in 13th-15th-century Tabriz, Leiden, Boston 2014, 129-168.

Pourjavady, R., Philosophy in early Safavid Iran, Leiden, Boston 2011.

Rapoport, Y., Legal diversity in the age of taqlìd: The four chief $q a \bar{a} d \bar{\imath}$ s under the Mamluks, in Islamic law and society 10 (2003), 210-228.

Reinhard, W., Zwang zur Konfessionalisierung? Prolegomena zu einer Theorie des konfessionellen Zeitalters, in Zeitschrift für Historische Forschung 10 (1983), 257-277.

Reinhard, W., Reformation, Counter-Reformation, and the early modern state. A reassessment, in Catholic historical review 75 (1989), 383-404.

Reinhart, A.K., On Sunni sectarianism, in Y. Suleiman and A. Al-Abdul Jader (eds.), Living Islamic history: Studies in honour of Professor Carole Hillenbrand, Edinburgh 2010, 209-225.

Romanov, M., Algorithmic analysis of medieval Arabic biographical collections, in Speculum 92/S1 (2017), S226-246.

Sariyannis, M., The Kadizadeli movement as a social phenomenon: The rise of a "mercantile ethic"?, in A. Anastasopoulos (ed.), Political initiatives from the bottom-up in the Ottoman Empire, Rethymno 2012, 263-289.

Savaş, S., XVI. asırda Anadolu'da Alevilik, Ankara 2002. 
Schilling, H., Confessional Europe, in T.A. Brady, H.O. Oberman, J.D. Tracy (eds.), Handbook of European history, ii, Leiden 1995, 641-670.

Stewart, D., Polemics and patronage in Safavid Iran:The debate on Friday prayer during the reign of Shah Tahmasb, in BSOAS 72 (2009), 425-457.

Terzioğlu, D., Confessional ambiguity in the confessional age: Philo-Alidism, Sufism and Sunni Islam in the Ottoman Empire, 1500-1700, in T. Krstić and D. Terzioğlu (eds.), Entangled confessionalizations? Dialogic perspectives on politics of piety and community building in the Ottoman Empire, 15th-18th centuries, forthcoming.

Terzioğlu, D., Sufi and dissident in the Ottoman Empire: Niyāzī-i Mıṣrī (1618-1694), PhD diss., Harvard University 1999.

Terzioğlu, D., Sufis in the age of state-building and confessionalization, in C. Woodhead (ed.), The Ottoman world, Abingdon 2012, 86-99.

Terzioğlu, D., Where catechism meets 'ilm-i hal: Islamic manuals of religious instruction in the Ottoman Empire in the age of confessionalization, Past and present 220/1 (2013), 79-114.

Terzioğlu, D., How to conceptualize Ottoman Sunnitization: A historiographical discussion, Turcica 44 (2012-2013), 301-338.

Terzioğlu, D., Sunna-minded Sufi preachers in service of the Ottoman state: Nașihatnāme by Hasan addressed to Murad IV, in Archivum ottomanicum 27 (2010), 241312.

Tezcan, B., The second Ottoman Empire: Political and social transformation in the early modern world, Cambridge, New York 2010.

Al-Tikriti, N., Ibn-i Kemal's confessionalism and the construction of an Ottoman Islam, in C. Isom-Verhaaren and K.F. Schull (eds.), Living in the Ottoman realm: Empire and identity, 13th to 2oth centuries, Bloomington, IN 2016, 95-107.

Al-Tikriti, N., Kalām in the service of the state: Apostasy and the defining of Ottoman Islamic identity, in H. Karateke and M. Reinkowski (eds.), Legitimizing the order: The Ottoman rhetoric of state power, Leiden 2005, 131-150.

Tuşalp Atiyas, E., The "Sunna-minded" trend, in M. Sariyannis, A history of the Ottoman political thought up to the early nineteenth century, Leiden 2019, 233-278.

Üstün, İ. S., Heresy and legitimacy in the Ottoman Empire in the sixteenth century, PhD diss., University of Manchester 1991.

Wensinck, A.J., The Muslim creed: Its genesis and historical development, New York 1932. Wiederhold, L., Blasphemy against the Prophet Muhammad and his companions (sabb al-rasul, sabb al-ṣahābah): The introduction of the topic into Shafi'i legal literature and its relevance for legal practice under Mamluk rule, in Jss 42 (1997), 39-70.

Winter, S., Shams al-Dīn Muhammad ibn Makkī "al-Shahīd al-Awwal" (d. 1384) and the Shi'ah of Syria, in MSR 3 (1999), 149-182.

Winter, S., The Shi'ites of Lebanon under Ottoman rule, 1516-1788, Cambridge 2010.

Yıldırım, R., Sunni orthodox vs. Shicite heterodox? A reappraisal of Islamic piety in 
medieval Anatolia, in A.C.S. Peacock, B. De Nicola and S.N. Yıldız (eds.), Islam and Christianity in medieval Anatolia, Farnham 2015, 287-308.

Ylldırım, R., Literary foundations of the Alevi tradition: Mainstream, canon and orthodoxy, in B. Weineck and J. Zimmermann (eds.), Alevism between standardisation and plurality: Negotiating texts, sources and cultural heritage, Berlin 2018, 61-96.

Yıldız, S.N., From Cairo to Ayasuluk: Haci Paşa and the transmission of Islamic learning to Western Anatolia in the late fourteenth century, in JIS 25:3 (2014), 263-297.

Yllmaz, H., Caliphate redefined: The mystical turn in Ottoman political thought, Princeton 2018.

Yürekli, Z., Architecture and hagiography in the Ottoman empire: The politics of Bektashi shrines in the classical age, Farnham 2012.

Zilfi, M.C., The Kadizadelis: Discordant revivalism in seventeenth-century Istanbul, in JNES 45 (1986), 251-269. 